\section{Research Article}

(c) 2021 Tahir et.al.

This is an open access article licensed under the Creative Commons Attribution-NonCommercial 4.o International License

(https://creativecommons.org/licenses/by-nc/4.o/)

Received: 15 October 2020 / Accepted: 23 December 2020 / Published: 17 January 2021

\title{
Eradicating Gender-Based Violence against Female-Intimate Partner in Pakistan: A Theoretical Framework from Islamic Philosophy
}

\author{
Dr. Muhammad Tahir \\ Assistant Professor, Head, Department of Islamic Studies, \\ Faculty of Social Sciences \& Humanities, \\ Riphah International University, near Hajj Complex, I-14, \\ Islamabad 46ooo, Pakistan

\section{Dr. Aayesha Rafiq} \\ Consultant Professor, Faculty of Arts and Social Sciences, \\ GIFT University, Sialkot Bypass, Lohian Wala, \\ Gujranwala, Punjab 52250, Pakistan

\section{Dr. Musab Yousufi} \\ Assistant Professor, Riphah Institute of Public Policy, \\ Faculty of Social Sciences \& Humanities, \\ Riphah International University, near Hajj Complex, I-14, \\ Islamabad 460oo, Pakistan

\section{Dr. Muhammad Kashif Sheikh} \\ Assistant Professor, Department of Islamic Studies, \\ Faculty of Social Sciences \& Humanities, \\ Riphah International University, near Hajj Complex, I-14, \\ Islamabad 460oo, Pakistan
}

DOI: https://doi.org/10.36941/ajis-2021-0029

\section{Abstract}

Gender-based violence has been an enormous family and social issue in human history. Not a single country or nation is free from domestic violence and abuse against women. In particular, violence against femaleintimate partner has become an endemic social issue at an alarming rate in Pakistan. Generally, it is regarded as a personal family matter and has become widely spread in the urban and rural areas of the country. Traditionally, women have to bear discrimination, subjugation, and violence in the daily routine that is grounded in the misuse of tribal traditions, social customs, and cultural norms. However, there is little focus on its assessment, intervention, prevention, and strategic solutions in the country. The present research tends to discuss violence issues relating to female-intimate partner in the Pakistani context. The findings identify that certain factors promote violence while Islamic philosophy suggests preventative measures and eradication strategies for violation and brutality against female-intimate partner. The study employs an analytical methodology using content analysis to review textual data of the Qur'an, Hadith, reports, and articles. The study approaches the issue differently from an Islamic theoretical framework and would be imperative for practical application in the protection and care of female-intimate partner in Pakistani society.

Keywords: violence, female-intimate partner, Pakistan, Islamic philosophy 


\section{Introduction}

Gender-based violence against female-intimate partner has become a pervasive issue worldwide. In literature, it is denoted as "domestic abuse, spousal violence, male violence, intimate partner violence, and family violence" (Usman, 2018: 3184, Tabassum, 2016: 101). Saeed (2012: 8) defined domestic violence as: "A range of behaviors perpetrated by an intimate partner (husband) and other family members against women and girls both in the domestic and public spheres." The gender-based violence is defined as: "Any act of gender-based violence that results in, or is likely to result in, physical, sexual or mental harm or suffering to women, including threats of such acts, coercion or arbitrary deprivation of liberty, whether occurring in public or in private life" (WHO, 1996: 5-6). This definition is approved by the Law, Justice and Human Rights Ministry of Pakistan (NIPS Pakistan and ICF International USA, 2013: 213).

Violence against female-intimate partner is growing drastically and this eruption is more intense in all areas of Pakistan. Violence is observed as a defilement of human rights (Aslam et al. 2015: 2) that affected all socio-economic and educational classes of women's life (Ali and Bustamante-Gavino, 2007: 1418-19). One in three women, about 35\%, have been suffering from abuse or beating into sex in her life-time worldwide (WHO, 2017: 1). In Pakistan, mothers transmit spousal violence to daughters as learned behavior and marital norm (Aslam et al. 2015:2). The majority of physical violence cases against women remain unreported officially which involves the disincentives of the victim and her family (Andersson et al. 2009: 1966). The female-intimate partner avoids reporting brutality and crime against male-spouse for two reasons: 1) reputation, disrespect, and bad image of her family and 2) unfair legislation system and exploitation of police (Muneer, 2017: 93-94). Generally, the wife does not like to terminate the violent and unhappy relationship with the husband for family-status, family-honor and the stigma of divorce (Jalil et al. 2013: 178).

In Pakistan, domestic violence is considered a family affair that has nothing to do with laws and rights, therefore, no need to report or consult it. There is little quantitative evidence indicating types of violence against women (Andersson et al. 2009: 484). It has become a ubiquitous phenomenon in Pakistani society (Social Policy and Development Center, 2012). Pakistan is at sixth position among dangerous countries for women in the world (Thomson Reuters Foundation Experts' Survey, 2018). Generally, violence against female-intimate partner has been perpetrated by the husband and in-laws (Human Rights Commission of Pakistan, 2013: 173), which sometimes causes woman's death (Country Information and Guidance, 2016: 22). Frequently, the cultural role is challenged by the family members, especially for family responsibility and social obligation (Dildar et al. 2012: 668). There is no adequate study or research to provide an accurate profile of violence against female-intimate partner in the country. However, the researchers have conducted individual research to underpin the intensity and severity of the issue at the local level. For example, Rizvi et al., (2019:3) found 59.9\% women experience violence in Pakistan. Likewise, Ali (2016) reported the prevalence of domestic violence ranges from $21 \%$ to $50 \%$. According to the articles published during the years 1998 to 20o8, violence against intimate partners ranges from $30 \%$ to $79 \%$ (Khan et al. 2007: 54).

\section{Research Methodology}

The present research employs an analytical research methodology using content analysis. Content analysis is "a research technique for making replicable and valid inferences from texts (or other meaningful matter) to the contexts of their use" (Krippendorff, 2003: 18). It is "a method that uses a set of procedures to make valid inferences from the text" (Weber, 1990: 9). Content analysis involves a content/textual analysis of data by collecting, comparing, contrasting, categorizing, and interpreting it (Schwandt, 2001: 21), for making inferences and conclusions. For the current investigations, textual data is searched out from the abstracts, article titles, topics, and sub-topics using the terms relating to violence against female-intimate partner and reference lists of online and published articles. For inclusion, 210 research papers, 20 books, and 11 reports were screened out to violence against femaleintimate partner. Table 1 demonstrates the steps that were taken to articulate the whole documents using qualitative research methodology: 


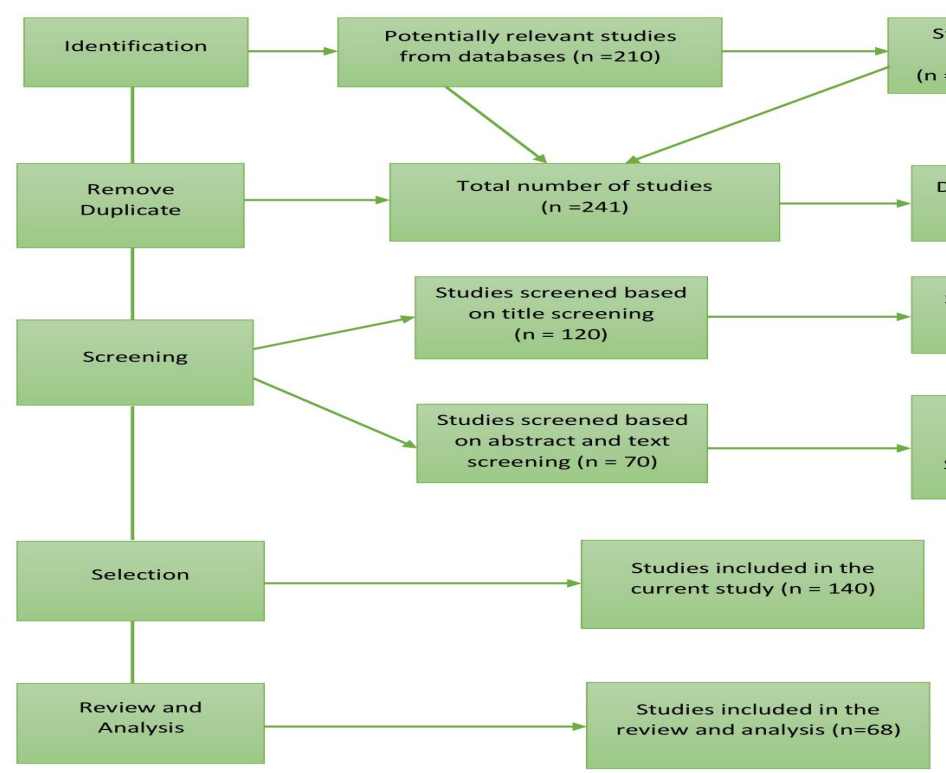

\section{Types of Violence against Female-Intimate Partner in Pakistan}

The researchers categorized violence against women into physical, emotional, psychological, economic, and sexual (Ali et al. 2014: 10). The table 2 presents different forms/ types of intimate partner violence in Pakistan:

Table 2: Forms/Types of Violence against Female-Intimate Partner in Pakistan

\begin{tabular}{|c|c|}
\hline $\begin{array}{l}\text { Physical } \\
\text { Violence }\end{array}$ & $\begin{array}{l}\text { slapping, hitting, shoving, pushing, kicking, grabbing, pinching, biting, hair pulling, burning, } \\
\text { beating, acid throwing, ritual honor killings, custodial abuse, torture }\end{array}$ \\
\hline $\begin{array}{l}\text { Verbal } \\
\text { Violence }\end{array}$ & $\begin{array}{l}\text { abusive language, excessive loudness, threatening to divorce, blaming, taunting, criticizing, } \\
\text { aggression, shouting, and yelling }\end{array}$ \\
\hline $\begin{array}{l}\text { Psychological } \\
\text { Violence }\end{array}$ & $\begin{array}{l}\text { persecuting, insults, belittling, feeling anxious, constant humiliation, intimidation, degradation, } \\
\text { constant criticism, suspension, character assassination, seclusion, diminishing abilities, name- } \\
\text { calling, depression, upset due to conflicts, threats of harm, taking away children, forced isolation } \\
\text { from family, other relations and school or work }\end{array}$ \\
\hline $\begin{array}{l}\text { Sexual } \\
\text { Violence }\end{array}$ & $\begin{array}{l}\text { forced marriage, child marriages, barter marriages, exchange marriages, forced sexual intercourse, } \\
\text { non-consensual sex, sexual coercion, forms of sexual coercion including marital rape, forcing sex, } \\
\text { attacking sexual parts, treating in the sexually demeaning manner, the husband's unmet sexual } \\
\text { needs, forced prostitution, medicating wife for forced, frequent and repeated sex, pushing to get } \\
\text { pregnant after } 4 \text { o days of a child's birth }\end{array}$ \\
\hline $\begin{array}{l}\text { Economic or } \\
\text { Monetary } \\
\text { Violence }\end{array}$ & $\begin{array}{l}\text { making financial dependence, controlling financial resources, denial of funds and foods, withholding } \\
\text { money access, forbidding attendance at school or employment, controlling access to primary health } \\
\text { care }\end{array}$ \\
\hline $\begin{array}{l}\text { Cultural } \\
\text { Violence }\end{array}$ & $\begin{array}{l}\text { harmful cultural practices, including: Dowry, Watta Satta (exchange marriage), Vani or Swara } \\
\text { (forced child-marriage) }\end{array}$ \\
\hline
\end{tabular}

Sources: LaBore et al., 2019: 4, 9, 11, Usman, 2018: 2, 3, 9, Ali et al., 2018: 1-2, 10-11, Abdul Hadi, 2017: 301, Karmaliani et al., 2017: 10-11, Tabassum, 2016: 103, Awais et al., 2015: 222-23, Siddiqui et al., 2015: 919, Ahmed, 2014: 368, Ali et al., 2011: 132, Bhatti et al., 2011: 150, Ibrahim \& Abdalla, 2010: 331-332, Kapadia et al., 2010: 164, Ali et al., 2009: 9-77, Zareen et al., 2009: 292, Hussain and Khan, 2008: 25-26, 472-73, Rabbani et al., 2008: 419, Ali and Bustamante-Gavino, 2007: 1420, Fikree et al., 2006: 253, Ali et al., 2005: 229 


\section{Factors Promoting Violence against Female-Intimate Partner in Pakistan}

Traditionally, the researchers identified many factors precipitating women's violence, which are categorized into types: intrinsic and extrinsic. The intrinsic factors are biological and personal while the extrinsic factors constitute the context within which the violence abuse takes place (Ali and Bustamante Gavino, 2008: 200). The table 3 identified these factors in the Pakistani community:

\section{Table 3: Factors Promoting Violence against Female-Intimate Partner in Pakistan}

\begin{tabular}{ll}
\hline $\begin{array}{l}\text { Intrinsic } \\
\text { Factors }\end{array}$ & $\begin{array}{l}\text { age, personality traits, education, interpersonal violence, income, substance abuse/ drug addiction, } \\
\text { witnessing marital violence in childhood, childhood abuse, father absentee, father rejecting personality, } \\
\text { modeling }\end{array}$ \\
\hline $\begin{array}{l}\text { Extrinsic } \\
\text { Factors }\end{array}$ & $\begin{array}{l}\text { male dominance, daily conflicts, decision disagreements, choice preferences, family problems, } \\
\text { dependency on man, low level of education, low socio-economic status, lack of rights' awareness, low } \\
\text { level of religious support, false beliefs about women, the concept of wife as property (possessive }\end{array}$ \\
& instinct), male's dominating social settings, imbalanced empowerment issues, lack of Government's \\
& support, marriage under 18 years, parents' marriage decisions or forced marriages, going out or to \\
& parents home without permission, conflicts about family planning, infertility and failure to produce a \\
& son, aggressive behavior of the wife, inter-familial conflicts, joint family system, absence of public \\
& support, gender discrimination, social shaming, fear of social stigma, structural and legal irritants, lack \\
& of domestic violence laws, Pakhtunwali (Pakhtun nationalism), husband-wife frustration, suspected \\
infidelity of husband, mother advising ways of behaving with in-laws, illicit relations of wife, lack of \\
mutual understanding, sickness of wife, infecundity, understandings of religious texts, use of social \\
media, household chores, disobeying in-laws, arguing with in-laws, misinterpretations of Islamic \\
thoughts and cultural values, unjust customs of dowry, ancient traditions, pighor (taunting to remind \\
one's defamed past), ignoring women's autonomy, males' inherent superiority, nonconsensual sex, \\
unfair male dominance in all matters
\end{tabular}

Sources: Khan et al., 2019: 374, LaBore et al., 2019: 1-4, LEAD Pakistan, 2019, Abbas et al., 2018: 108109, Amir-ud-Din et al., 2018: 5, Usman, 2018: 1, Khawaja, 2017: 98, Ghani, 2016: 205-206, Niaz and Hassan, 2016: 119, Qaisrani et al., 2016: 11, Shaikh, 2016: 23-28, Sultan et al., 2016: 35-37, Abdul Aziz and Janine, 2015: 11, Ali et al., 2015: 27, Ali, 2014: 2-3, Manzoor et al., 2013: 358, 359, 363, Saeed, 2012: 142, Shah et al., 2012: 50, Zainab et al., 2012: 249, Khan and Sajid, 2011: 2171-2172, Nosheen, 2011: 292, Ali et al., 2009: 9-77, Khan et al., 2009: 55, Farid et al., 2008: 141, Ali and Bustamante-Gavino, 2007: 1422-23, Fikree et al., 2005: 56, Welchman and Hossain, 2005: 6, 11

\section{Health Effects of Violence against Female-Intimate Partner}

Typically, violence against women has negative influences on individuals, families and societies (Khatoon et al., 2014: 14). No walks of life are protected from the adverse consequences of gender-based violence like married life, children, family members, relatives and society (Finker, 1997: 1152-53). It has severe consequences on mental, physical, psychological, and reproductive health of women (Khan et al., 2019: 374, Amir-ud-Din et al., 2018: 2, Karmaliani et al., 2017: 18, Sultan et al., 2016: 33), which may cause disability and death (WHO, 2013: 8). Perhaps the most severe consequence is considered a denial of fundamental women's rights. The table 4 highlights the effects of violence on health of women in Global and Pakistani context:

Table 4: Health Effects of Violence against Female-Intimate Partner

\begin{tabular}{ll}
\hline Physical & acute and severe physical injuries, gastrointestinal conditions, fractures, wounds, skeletal \\
Effects & deformations, gastro-intestinal problems, abdominal injuries, vaginal lacerations, forced abortions, \\
& pregnancy loss, brutal beatings, suicides, genital infections, HIV-infection, death
\end{tabular}


Psychological anxiety, depression, stress and anxiety disorders, eating and sleeping disorders, suicide thoughts and Effects attempts, self-harm, prolonged stress and psychiatric problem, post-traumatic stress syndromes, phobias, eating disorders, sleep disorders, PTSD, well-being issues, emotional issues, mental health and self-confidence, short-term and long-term traumas and traumatizing, aggression and abusecycle, excessive violence, drug dependency, drug abuse, drugs addiction, mental problems, psychological disorders

Reproductive sexual harassment, sexual infections, miscarriage, vaginal, pelvic, urinary infections, fistula, sexual Effects dysfunction, sexual relationships, nonconsensual sex

Family \& children witnessing violence at home or being abused may exhibit health issues and behavior Social Effects problems at school with peer relations, and weight, eating, and sleep problems, separation, divorce, and disturbance for children's life, high divorce rates, immodesty, immorality, extra-marital relationships,

Sources: Psych Central, 2020, Domestic Violence Hotline, 2019, Yasien et al., 2018: 1432, Pingley, 2017: 22-25, Sultan et al., 2016:33, WHO \& PAHO, 2012: 2, Haqqi and Faizi, 2010: 1095, Kumar, 2010, Spitzberg, 2009: 224, Zareen et al., 2009: 295, Ayub et al., 2009: 958, Wahed and Bhuiya, 2007: 347, Ilyas and Jenkins, 2004: 2, 4, Shaikh, 2000, 313

\section{Islamic Theoretical Framework for Eradicating Violence against Female-Intimate Partner in Pakistani Context}

Islamic philosophy enshrined women's high status in society. Islamic ethical system has no place for gender discrimination and exploitation (Ahmad, 2019: 47). In the Muslim community, women's rights are rooted in its religious and legal systems (Zia-Ullah, 2010:4). In Pakistani culture, Islamic injunctions are compromised with cultural and social misdeeds (Bhattacharya, 2014: 182). Gender-based violence has been extremely rooted in the structure of relationship, nationalism, warfare, and religion (Merry, 2006: 56). There is an urgent need to encounter violence against women in Pakistan (Asia Report $\mathrm{N}^{\circ}{ }_{26}$, 2015: 1). The subsequent discussion examines an Islamic theoretical framework for the eradication of gender-based violence against female-intimate partner in Pakistan:

\section{1) Identification of Wife's Respect and Honor}

In Pakistan, patriarchal values determine the subordinate status of women and promote abnormal, immoral, and harmful customary practices (Ibad and Batool, 2017: 15, Noor, 2004: 8). In the provincial areas, women are deprived of their fundamental rights (Gul et al., 2018: 2). Significantly, Islam assigns an elevated high position to female-intimate partner. The status of wife is described in Qur'an as, "He created for your wives from among yourselves, that you may find repose in them, and He has put between you affection and mercy" (Qur'an, 30:21) and in the hadith as, "The best of you is the one who is best to his wife" (Ibn Mājah, 2007:3/131, At-Tirmidhī, 2007: 2/530-31). The hadith encourages kind and cheerful conduct with the wife (Al-Najdī, 2002: 1/204). Therefore, in Islamic tradition, female-intimate partner receives a high status that assures her protection, security, and care for successful married life and healthy relationships. Consequently, there is a current need of the recognition of wife's respect and honor to control brutality and violation of the husband in Pakistani society.

2) Understanding Wife's Status of Equality

In Pakistani society, gender inequality is embedded into cultural values of reinforcing male's conventional roles as head, in-charge, and decision-maker of all family matters (Amir-ud-Din et al., 2018: 3). In the subcontinent, cultural values and social norms established under regional traditions and local tribal values with no dynamic connections to the Islamic system of ethics and values. Therefore, women's status of equality is understood within the cultural context. The Qur'an and Sunnah strictly observed justice, fairness, and equality of gender by granting women equality in legal, economic, and social rights (Ahmad, 2019: 5, 65). The Qur'an declares gender-equality in accepting religious injunctions (Qur'an, 33:36), protection, and safety (Qur'an, 33:58), punishments on the Day of Judgment (Qur'an, 85: 10). Surprisingly, 
women accord more care and protection in accusation matters than men (Qur'an, 24:4, Qur'an, 24:23). Allah Almighty will reward both genders equally in accordance with their deeds on the Day of Judgment (Qur'an, 33:35). Moreover, the Qur'an states: "And whoever does righteous good deeds, male or female, and is a believer, such will enter Paradise and not the least injustice, even to the size of a speck on the back of a date-stone, will be done to them" (Qur'an, 4:124).

Islam approaches issues of gender-equality from a humanistic and ethnocentric perspective while considers ethical performance as the basis of superiority, not gender. To allow Muslim women to enjoy their Islamic rights, the un-Islamic practices and customs must be brought in line with the ethical principles of Islamic teachings (Ahmad, 2019: 2, 5). Islam, however, assigns different roles to the husband and the wife in worldly affairs in accordance with their abilities and capacities, which may protect them from any defilements and harms.

3) Premarital Considerations for the Decision and Selection of Spouses

In Pakistani culture, a marriage contract is the only legitimate socially acceptable method for an intimate relationship (Ali et al., 2018: 1, Ali et al., 2014: 4). Marriage is understood as a family, public, and social affair (Hamid, 2010: 5). The cultural practices deny the right of women to choose or reject marriage partners (Siddiqui et al., 2015: 925), due to inexperience, family pressure, obedience, and modesty (Saddique, 2017: 1661). Generally, the family members control marriage and divorce decisions (Wasim et al., 2008: 30-31), particularly parents. In historical context, even in recent times, it has been a common practice of parents or elders to choose spouses for their youngsters or impose their personal decisions without consulting them. With time, cultural trends of selecting spouses have been changed slightly, and parents, not in all cases, started taking consent of their youngsters or allow them to choose spouses, considering parents' final authority in the marriage decision.

Islamic philosophy recommends definite steps, if considered while making intimate partner choice, which could help to curb domestic violence. First, Istikhara can be done for seeking Allah's guidance in searching the suitable marriage-partner. It is "a non-obligatory prayer followed by the supplication for seeking God's guidance in matters of uncertainty" (Bukhārī, 1997, 2/157). Second, the qualities of a man (would-be-husband) include: religion (practicing Deen) and character (At-Tirmidhī, 2007: 2/455), strong (physically and religiously), trustworthy (Qur'an, 28:26), and righteous (Muslim, 2007: 4/161-62). Third, the qualities of a woman (would-be-wife) include: religion (practicing Deen) (Bukhārī, 1997: 7/32-33), righteousness (Saliha) (Muslim, 2007: 4/127) piousness (Ibn Hibbān, 1993, 9/340), loving and fertile (Abu Dawūd, 2008: 3/501-502), and the best for progeny (Ibn Mājah, 2007: 3/126). Fourth, Islam allows taking the consent of the man (would-be-husband) and the woman (would-be-wife) for marriage choice, as stated in the Qur'an, "Marry the woman of your choice" (Qur'an, 4:3), and "O believers! You are forbidden to inherit women against their will" (Qur'an, 4:19) and the Prophet (PBUH) said, "Seek the permission of women with regard to marriage" (An-Nasai, 2007: 4/123). Fifth, the Prophet (PBUH) recommended a matron to marry a righteous (Salih) man (Ibn Mājah, 2007: 3/160). Sixth, the husband and wife are allowed to look at each other before marriage for creating love between them (Ibn Mājah, 2007:3/70). To summarize, Islamic selection criteria, if investigated before making a marriage choice, may promote love, care and respect between the husband and the wife for a successful marriage and a suitable home environment.

4) Establishing Mutual Responsibilities and Rights of Intimate Partners

Generally, women are unaware of their responsibilities and rights in Pakistan. Domestic violence results from the lack of education and ignorance about Islamic values (Chaudhry, 2004: 671). To control female domestic violence, educational and health awareness programs are suggested (Khan et al,. 2009: 54-56). In Pakistani society, the husband-wife relationship remains under the cultural influences and elders' guidance that has a little concern to the Islamic understanding of family-life and may cause family conflicts leading to violence and abuse. 
Islam highlights the duties and rights of husband and wife, which, if fulfilled justly and sincerely, can play a significant role in eradicating issues of violence against wife. The responsibilities of the husband are described as: "The man is a guardian of his family and responsible for his charges" (Bukhārī, 1997:3/420) "The best of you is the one who is best to his wife" (Ibn Mājah, 2007, 3/131) and, "And their [women's] rights over you are that you treat them well in clothing them and feeding them" (At-Tirmidhī, 2007: 2/531). "Treat women nicely" (Bukhārī, 1997, 4/329) and "And I command you to take care of the women in a good manner" (Bukhārī, 1997: 7/81).

Conversely, the responsibilities of the wife are mentioned as: "A woman is a guardian of her husband's house and responsible for her charges" (Bukhārī, 1997: 3/420), "As for your rights over your women, then they must not allow anyone whom you dislike to tread on your bedding nor to admit anyone in your home that you dislike" (At-Tirmidhī, 2007, 2/531), and "A pious wife that helps you in your worldly and religious affairs is better than what people have accumulated" (Al-Baihqī, 2003: 6/247). The Prophet (PBUH) mentioned an ideal woman as: "which woman is best?' He said: 'The one makes him [husband] happy when he looks at her; obeys him when he commands her, and she does not go against his wishes with regard to herself nor her wealth" (An-Nasai, 2007: 4/102). Likewise, the Prophet (PBUH) said, "Any woman who dies when her husband is pleased with her, will enter Paradise" (Ibn Mājah, 2007, 3/64).

To conclude, the husband is responsible for economic (financial) matters and well fitted for outdoor obligations and the wife is more likely to do household activities and well equipped for indoor responsibilities. The husband and wife can accomplish mutual roles, duties, and rights to provide a healthy home environment, otherwise, misunderstandings can ultimately indulge them into violent actions against each other.

5) Addressing Patriarchal Perceptions and Patrilineal Culture

Literally, patriarchy refers to the male rule as a head in a society (Pilcher and Whelehan, 2004: 93). It is male domination in private spheres and public sectors (Sultana, 2012:2) that aims at repression and subjugation of females in the family (Habiba et al., 2016: 212). Generally, gender inequality is associated with "patriarchal gender system" (Offenhauer, 2005: 1). In Pakistani patriarchal perceptions and patrilineal culture, couples live together in an extended or joint family system (Laila Tul Qadar, 2018: 3, Khan et al., 2019: 376, Tarar and Pulla, 2014: 56) that influences the marital relationships of spouses significantly (Ali et al., 2018:3). The patriarchal values are rooted in society to determine the subordinated role and status of women (Madhani et al., 2017: 78). The patriarchy necessitates ferocity and subjugation against women for its existence (Abdul Hadi, 2017: 298). There is a current need for unlearning patriarchal perceptions and patrilineal culture (Gul et al., 2018: 4).

In Islam, patriarchal and patrilineal cultures have no space at all, and none has excellence over others except piety (At-Taqwa) (Qur'an, 49:13) and all humans are children of Adam (AtTirmidhī, 2007: 5/574). The Prophet (PBUH) declared during his Farewell sermon, "There is no favor of an Arab over a foreigner, and nor a foreigner over an Arab, and neither white skin over black skin nor black skin over white skin, except by righteousness" (Ahmad, 2001: 5/ 411). It means the Muslim husband can stop patriarchy culture completely by following Islamic injunctions underpinning women status. In Islamic tradition, a wife or a daughter or a sister [or a mother] may be much more superior to male members of the family based on "taqwa" (Allah consciousness), "birr" (virtue, piety), and "akhlaq" (ethics), as these are the basis of superiority in Islam (Ahmad, 2019: 16). Moreover, the acknowledgment and implementation of responsibilities and rights of the husband and the wife can reduce the severity of patriarchy culture in Pakistani society.

6) Providing Wife's Economic and Financial Rights

Traditionally, violence against wife is also grounded in economic issues and poverty in Pakistan. Nevertheless, Islam introduces the economic rights of wife and assigns the husband role of a provider, in-charge, protector, and guardian of the family. Islam grants the woman pervasive rights of inheritance from her father, husband, offspring, and other near relatives 
(Maududi, 1987: 144, 150). Islam establishes the financial and economic rights of women, especially wives (Qur'an, 2:233). The husband is held responsible and accountable as a guardian, as stated, "The man is a guardian of his family and responsible for his charges" (Bukhārī, 1997: 3/420) and as a woman's sustainer and maintainer, as quoted: "And their [women] rights over you are that you treat them well in clothing them and feeding them" (AtTirmidhī, 2007: 2/531). The husband would be sinful for neglecting the rights of the family (Muslim, 2007: 3/43-44, Abu Dawūd, 2008: 2/316-17) and would be asked about his family's responsibility and accountability on the Day of Judgment (Ibn Hibbān, 1993: 10/345). Therefore, in Pakistan, there is a current need to give awareness of women's economic rights to diminish the actions of violation and subjugation, and the application of the Muslim Family Law would be supportive in promoting wife's economic rights.

7) Promoting Mutual Discussion and Agreement in Family Matters

In Pakistan, men play an authoritative role in all family and social matters, whereby women's role is no more than doing household works and home activities. The family structure and function have neglected women's negotiations in all spheres of life (Khawaja, 2017: 96). Islam recommends consultation in worldly matters to the Prophet (PBUH) (Qur'an, 3:159) and companions (Qur'an, 42:38). The importance of consultation can be highlighted from the first revelation (Wahi), when the Prophet (PBUH) discussed the whole matter with his wife Khadija and accepted her suggestions of visiting her cousin Warqa bin Naufal (Bukhārī, 1997: 1/46-48). Essentially, Islamic injunctions provide impeccable guidelines in family matters for gender-equality. The Qur'an recommends mutual consultation of the husband and the wife in weaning the child, as stated: "If they both decide on weaning, by mutual consent, and after due consultation" (Qur'an, 2:233). Consequently, mutual discussion strategy may facilitate the domestic matters in a more sophisticated way to remain in harmonious concord between spouses and continue family relations smoothly and properly. However, Islam assigns the husband an additional responsibility of leadership rather than a dictatorship or authoritative role.

8) Eradicating Physical, Psychological, and Sexual Violence

The physical, psychological, and sexual violence against women are rooted into the tribal and cultural context in Pakistan. Traditionally, it is assumed that beating a woman is a man's right. In most cases, battered women are suggested to "continue to suffer to prevent family breakup/ divorce" or "wait till your children grow up" (Kapadia et al., 2010: 165), or "respect for elders and in-laws" or "hope abuse will stop" (Madhani et al., 2017: 78). The wife-beating is a relatively common phenomenon among the educated and economically privileged classes (Siddiqui et al., 2015: 926-27). The culturally acceptable intervention techniques are needed to eradicate wife-beating in rural areas of the country (Jalil et al., 2013: 182). The main identifiable reasons for female acid attack include: a husbands preexisting domestic abuse and a big family dispute in Pakistan and worldwide (Acid Survivors Trust International, 2016). Islam condemns the physical, psychological, and sexual violence against women. The Prophet (PBUH) never hit anyone, including woman (Muslim, 2007: 6/178) and forbade killing women or children (Bukhārī, 1997: 4/158-59). Islam allows light hitting to a woman (wife) on committing ill-conduct and exhibiting evil-behavior. Still, it would be followed in three steps: first, admonishing, second, refusing to share the bed, third, light beating. The Qur'an mentions the three steps as, "As to those women on whose part you see ill-conduct, admonish them, refuse to share their beds, beat them (lightly); but if they return to obedience, seek not against them means (of annoyance)" (Qur'an, 4:34). A tradition highlights the three steps to be followed strictly while dealing with the woman (At-Tirmidhī, 2007: 2/531), who manifests evil-behavior and ill-conduct, the three steps or ways include: 1) admonishing; 2) separating bed;3) light beating, not harmful. The above verse and tradition are taken out of context and misunderstood, misinterpreted, and misquoted to beat the woman abruptly (Ibrahim \& Abdalla, 2010: 344), which is not fair and just. Generally, men misuse religion to keep their 
dictatorship over women while ignoring the religious commandments. Islam grants concessions to a pregnant and breastfeeding woman while fasting in Ramadan for physical protection (An-Nasai, 2007: 3/238).

Islamic philosophy provides protection against psychological violence, as the Prophet (PBUH) advises men: "Treat women nicely" (Bukhārī, 1997: 4/329). Likewise, for sexual care of spouses, the Qur'an prevents having sexual relationships during menstruation period (Qur'an, 2:222). In Islam, intimate relationships are considered an act of reward and worship, as mentioned: "If he fulfills it [sexual desire] in a lawful manner [through marriage], he will be rewarded for it" (Muslim, 2007:3/51-52). Islamic teachings provide legal grounds to intimate relationships for chastity and recommend legitimate means of satisfying sexual urge and do not promote any sexual violence and abuse against wife. Therefore, the husband is responsible for sexual violence against the wife that ultimately has no concerns with the real essence of Islamic ideology.

9) Abolishing Dowry Culture and Practices

Dowry is "a transfer of parental property, gifts, or money at the marriage of a daughter rather than at the owner's death" (Goody, 1976: 6). It is an Indian tradition and custom embedded into Hinduism in which male and his family members demand material things from female's family before finalizing a marriage-contract (Hussain, 2003: 235). In Pakistan, dowry is called Jehez, a significant economic transaction for marriage decisions (Tabassum, 2016, 118). Dowry practice affects women's mental health for being continual torture perpetrated by inlaws, which causes them to commit suicide to avoid misfortune and grief (Gulzar et al., 2012: 785). The cases of dowry violence are increasing day-by-day, resulting in a woman's death (Ahmed, 2014: 368-69). The cultural dowry system is not an Islamic practice. Islam has granted the basic right of Mahr (bridal money) of the woman, which were twisted or ignored by the males in Indo-Pak male-dominant culture (Awan, 2004: 9). Islam recommends giving a woman's Mahr (bridal-money) while making a marriage contract, as stated: "and give to the women their Mahr with a good heart" (Qur'an, 4:4) and providing sustenance to the whole family (Qur'an, 2:233). The Qur'an prohibits the unjust usage of others' property (Qur'an, 3:188). Likewise, the Prophet (PBUH) rejected imposing any self-made conditions on others (Bukhārī, 1997: 1/289). Categorically, dowry is a cultural practice, which has no concern with the Islamic family system. Therefore, violence due to dowry can be stopped by observing Islamic injunctions that forbid it completely.

10) Stopping Child Marriages

Child marriage is "marrying [a girl] before the age of 18" (Wodon, 2015: 1). In tribal and rural areas of Sindh, the violent issues of child marriages and marriage with the Qur'an are pervasive (Ahmed, 2014: 368-69, Nosheen, 2011: 291). Child marriage is a common practice in Pakistan (Ashraf et al., 2017: 1403), which predisposes girls to intimate partner violence (Ali and Bustamante Gavino, 2008: 201). The Muslim Family Law Ordinance of Pakistan 1961 states that girls cannot be married before the age of sixteen years (Muslim Family Law Ordinance, 1961). In January 2019, "a legislative panel of the Parliament approved a draft bill raising the minimum age of marriage to 18 years" (Kakakhel, 2019). The constitution of Pakistan provides marital rights to women and protects them against the child or forced marriage arranged and managed by a guardian (Saddique 2017: 161). The causes of child marriage include: lack of awareness, lack of law implementation, consideration of children as commodities and slaves, tribal customs, feudal social structure, extreme conditions of poverty, and internal trafficking (Khoso, 2013: 1). Islam provides awareness for acceptance of betrothal through father/guardian and permission of marriage with the consent of the woman to make the practice acceptable (Bowden, 2013: 13, 13). In traditional Islamic law, the minimum age of Muslim women is not specified (Hussain, 2018: 165). Islam allows engagement (Nikah) without defining age; however, a wedding can take place after puberty/maturity with the consent of spouses (Qur'an, 4:3, 4:6, 4:19, An-Nasai, 2007: 4/123, Abu Dawūd, 2008: 2/526). Islamic teachings set conditions for marriage including, mutual consent of marriage couple, clear proposal and acceptance, woman's guardian or legal 
guardian, Islamic dowry (Mahr), two competent witnesses, and the sermon of marriage (Abd al-Ati, 1995: 60-62, Hussain, 2003: 147-152). Islam highlights mandatory requirements for a marriage contract to be fulfilled by spouses, which are examined in the preceding discussion of mutual responsibilities/ rights and recognition of the wife's economic rights.

\section{1) Eradicating Traditional Forced Marriage Practices}

The ancient and ancestral customs make women vulnerable to violence. Forced marriage is defined as a "marriage without the valid consent of both parties and where coercion or force is involved" (Kelly and Regan, 2006: 6). Honor and dishonor are the basic concepts of the culture of Pakistan (Lieven, 2011: 170). Honor killing gets its justification from prevalent patriarchal social values (Abdul Hadi, 2017: 300). Generally, honor killing does not provide a woman with an opportunity to prove herself innocent (Ashraf et al., 2017: 1408). In Pakistan, during the year 2015, 1100 females were killed due to the honor by their family members (Women-Rights of the disadvantaged, 2015:3). Honor Killing is defined as, "the killing of a female, typically by a male perpetrator, because of perceived or actual misconduct of the victim who has dishonored or shamed her family and clan by actually or allegedly committing an indiscretion" (Devers and Bacon, 2010: 360). Wani or Vanni or Vani refers to "a child marriage custom in tribal areas of Pakistan. It could be avoided if the clan of the girl agrees to pay money called Diyat" (Parveen, 2012: ix). Watta Satta refers to "a tribal custom in Pakistan of exchanging brides between two families" (Parveen, 2012: ix, Bhatti et al., 2011: 149).

Islam has never been a misogynist religion. Islamic philosophy provides legal foundations to condemn ignorant forced marriage practices for the protection and care of women. In Islam, there is no such punishment of honour killing and Wani or Vani. Nevertheless, the Qur'an highlights the protection and preservation of human life as, "If anyone killed a person, not in relation of murder, or to spread mischief in the land, it would be as if he killed all mankind" (Qur'an, 5: 32). The Qur'an ultimately condemns killing, as stated, "And do not kill anyone which Allah has forbidden" (Qur'an, 17:33). Likewise, the Islamic viewpoint is distinct regarding exchange marriage (Shighār), as it is not the concept of Islam, as mentioned in a tradition, "There is no Shighār in Islam" (Muslim, 2007, 4/40). The customs mentioned above are rooted in tribal and cultural systems in the areas of the country, which have no connection with the real essence of Islam. In the Pakistani context, the Prevention bills and acts provide legal protection to women's rights theoretically, not practically (Muneer, 2017: 87). To conclude, the practical application of Islamic teachings and implementation of laws can reduce such worse practices against women.

\section{2) Contextual Understanding of Religious Commandments and Texts}

In Pakistani society, people perceive domestic violence as permitted by religion (Zareen et al., 2009: 249) and misinterpret religious teachings (Niaz and Hassan, 2016: 119, Siddiqui et al., 2015: 914-15). The Qur'an explains the rights of women as: "And they (women) have rights similar (to those of their husbands) over them to what is reasonable, but men have a degree (of responsibility) over them" (Qur'an, 2:228). The above verse mentions total legal genderequality, and the words "a degree above" have been misunderstood to allow men full authority over women (Ahmad, 2019: 52). Such a degree is highlighted in the Qur'an, "Men are the protectors and maintainers [qawwam] of women, because Allah has made one of them to excel the other, and because they spend from their means" (Qur'an, 4:34). The verse mentions the word "qawwam" (overseers) that refers to functional authority rather than an absolute superiority and authority (Ahmad, 2019: 16). The degree refers to a man's responsibility of sustenance towards family and frees the woman [from this responsibility]; therefore, the man should be appointed a supervisor and maintainer of the woman [needs] (Islahi, 2009: 97). Islamic social system determines gender place and responsibilities on biological and psychological differences (Maududi, 1987: 148). In reality, the concept of supremacy of a man over a woman is grounded to cultural values and traditional norms that cause domestic abuse of women and have no relation to the religion. The Islamic notion of the role of the husband 
as a protector, caretaker, supporter, and compassionate family-head are needed to be promoted in the society (Sultan et al., 2016: 40).

13) Addressing Drug Addiction Issues of Husband

A study suggested that a husband's addiction to alcohol, addictive substances, and smoking significantly related to physical abuse against the wife (Awais et al., 2015: 222-23). Talking about Islam, it completely prohibits drugs, substances, and intoxicants (e.g., opium, alcohol, heroin, cocaine, and marijuana), which are entirely unlawful things. For instance, the Prophet $(\mathrm{PBUH})$ prohibited all intoxicants: "Every intoxicant is Khamr, and every intoxicant is unlawful (Harām)" (Muslim 2007: 5/353). Further, the Prophet (PBUH) said: "Every intoxicant is unlawful, and whatever causes intoxication in large amounts, a small amount of it is (also) unlawful" (Ibn Mājah, 2007: 4/386-87). The Prophet (PBUH) advised Abu Darda as, "Do not drink wine for it is the key to all evils" (Ibn Mājah, 2007: 4/377). The word "khamr" refers to "veil, cover, hide, conceal" (Baalbaki, 1995: 523). Hence, in Pakistani context, the prohibition of intoxicants, as highlighted in Islamic philosophy, can eradicate violation and subjugation in the family and society that is caused by drunk husbands. Besides, awareness of legal punishments and their side effects on health can control intoxicants' intake in youngsters and adults for social benefits.

14) Reflecting on Sterility/Infecundity Issues of Wife

In Pakistani culture, the sterility of women leads them to suffer from psychological and physical abuse. In common practice, a woman faces victimization of having infertility from the husband (Chaudhry, 2004: 671), in-laws, family members, relatives, and peers without undergoing a medical examination. Sometimes, long term infertility causes the beating and torturing of the woman, which eventually breaches the marriage bond. In addition, when a woman is pregnant with a girl-baby faces victimization in a male-dominant family structure in the country (Qaisrani et al., 2016: 11). Islamic teachings provide strategies to cope with infertility issues. Firstly, the Qur'an elucidates that, "He [Allah] bestows female (offspring) upon whom He wills, and bestows male (offspring) upon whom He wills. Or He bestows both males and females, and He renders barren whom He wills" (Qur'an, 42:49-50). The verse confers that Allah Almighty bestows whom he wills with children, and a woman can bear a child with Allah's will. Thus, Allah comforts Muslim men and women regarding fertility and infertility issues, referring to his final authority of bestowing with children. Secondly, Islam allows the use of medicine for the treatment of infertility issues in the light of Prophetic instruction: "There is no disease that Allah has sent down except that He also has sent down its treatment" (Bukhārī, 1997: 7/326), intending to receive cure from Allah Almighty (Qur'an, 26: 80). Hence, the husband and wife can undergo a medical examination to diagnose infertility issues and take treatment of medicine. Islam allows investigating the fertility of women by looking at her family background. Thirdly, a woman can be chosen for marriage by investigating her fertility to avoid domestic violence and subjugation due to her infertility. The Prophet (PBUH) recommended marrying a fertile woman (Ibn Mājah, 2007:3/67-68) and prohibited marrying an infertile woman (Abu Dawūd, 2008: 3/501-502) yet permitted marrying a matron (widow or divorced) for taking care of the children (Bukhārī, 1997: 5/23). A woman's fertility could be observed by exploring her family background, investigating the offspring of her sisters and brothers. In addition to that, the infertility issue of women can be solved by allowing a man to marry a second woman in Islamic tradition with the condition of doing justice between them (Qur'an, 4:3). Fourthly, the Prophet (PBUH) clarifies the reason for bearing a boy baby by saying: "The man's water is thick and white, and the woman's water is thin and yellow; whichever of them comes; first, the child will resemble" (An-Nasai, 2007: 1/135). The tradition refers to the resemblance of gender and temperament to parents (father and mother).

The scientific investigations are evident that a male's seminal fluid contains $X Y$ chromosomes, and a female's egg contains $X X$ chromosomes. To bear a boy baby $(X Y), Y$ chromosome of a male infuses with $X$ chromosome of a female as a result of fertilization (Bachtrog et al., 2014). 
Therefore, it is an unjust and ignorant practice to blame the wife for not bearing a boy-baby in Pakistani society. To conclude, Islamic teachings protect the wife from undergoing any domestic violence and subjugation in cultural context based on false assumptions and statements without taking a medical examination for not having children or bearing a boy-baby.

\section{Conclusion}

To conclude, the preceding discussion demonstrates the theoretical framework of Islamic philosophy to effectively address the issues of violence against female-intimate partner for practical application in the Pakistani family system. Mainly, Islamic teachings provide a pragmatic and flexible stance for stimulating ideas, encouraging thoughts, inspiring visions, and compelling grounds to eradicate issues of domestic violence against wife in Muslim societies worldwide. Ultimately, Islamic philosophy presents significant strategies for controlling and preventing the brutal attitudes and malice behaviors perpetrated by men against women, especially against wives. However, in Pakistani society, gender-equality and wife's rights are incredibly conservative rooted in ethnical context, patriarchal structure, tribal system, societal status, social classes, and female education. The present study provides a sensible overview and functional analysis of the causes and factors leading towards domestic violence against wife in Pakistan for delivering the ultimate preventative measures from Islamic philosophy. Indeed, Islamic strategies presented in the research can be imperative for eradicating the menace of gender-based domestic violence against wife and rigid gender-based roles of the husband and gender-based inequalities in the Pakistani culture. The research investigated that violence against the wife is mainly embedded in the traditional practices, cultural constructs, and social domains, which eventually may not be linked to Islamic ideology and the Islamic family system. Therefore, in curbing and reducing violence against wife in the country, the implementation of Islamic strategies highlighted in the paper would be incredibly supportive and practical. In this regard, an effective approach can be embraced by making individual and collective efforts underpinning with an organized, managed, sympathetic, cooperative, and sustainable manner. More significantly, the Islamic guidance and counseling strategy can be effective for protecting the husband (perpetrator) and wife (victim) and rehabilitating their relationships, keeping in view the five principles mentioned by UNICEF (2000: 14), including "prevention, protection, early intervention, rebuilding the lives of victim-survivors, accountability." For workable preventative measures against female-intimate partner violence in Pakistan, it is suggested to provide awareness about intimate partner violence through Islamic premarital education on married life, seminars, symposium, conferences, workshops, and trainings using different channels and electronic networks, including Deeni Madrassa, Mosques, schools, colleges, universities, social media, T.V. shows, NGOs, and Legal platforms.

\section{Acknowledgment}

This study has not received any grants and funds. The authors have no potential interest of conflict for this research.

\section{References}

Abbas, Safdar, Muhammad Hashim, and Ali Abdullah Mohammed Alzuhairi (2018) "Status of Rural Women: Patriarchy and Inevitability of Subjugation; A Study of Rural Area in Multan, Pakistan”. Journal of Education and Practice, 9, 6, 107-114.

Abd al-Ati, Hamdullah (1995) The Family Structure in Islam. Cairo: American Trust Publications.

Abdul Aziz, Zarizana and Janine Moussa (2015) "The Due Diligence Principle and the Role of the State: Discrimination against Women in Family and Cultural Life". United Nations Working Group on Discrimination against Women in Law and in Practice.

Abdul Hadi (2017) "Patriarchy and Gender-Based Violence in Pakistan". European Journal of Social Sciences Education and Research, 4, 4, 297-304. DOI:10.26417/ejser.v10i2.p297-304

Acid Survivors Trust International. (2016) Acid violence. Retrieved on January 17, 2020 from http://asfpakistan.org/wp-content/uploads/2017/o2/SAAV-report-2015.pdf 
Ahmad bin Hanbal, (2001) Musnad Ahmad. Cairo Mo'ssasah al-Rișālah.

Ahmad, Anis (2019) Gender, Law and Society in Islam. Islamabad: Institute of Policy Studies.

Ahmed, Shumaila (2014) "Violence against Women: Media Representation of Violent Issues in the Perspective of Pakistan". Science International, 26, 1, 367-371.

Al-Baihqī, Ahmad bin al-Hussain (2003) Sh 'ab al-Imān. Riyadh: Maktaba al-Rushd.

Ali, Bakhtawar (2014) "Domestic Violence against Women in Pakistan: A Meta Analytic Review of Published Researches", Escalating Research, 3, 4, 1-25.

Ali, Faridah A., Syed M. Israr, Badar S. Ali and Naveed Z. Janjua (2009) "Association of Various Reproductive Rights, Domestic Violence and Marital Rape with Depression among Pakistani Women, Pakistan”. BMC Psychiatry: 9-77, 1-13.

Ali, Parveen Azam, Alicia O'Cathain, and Elizabeth Croot (2018) “Influences of Extended Family on Intimate Partner Violence: Perceptions of Pakistanis in Pakistan and the United Kingdom". Journal of Interpersonal Violence, 1-29. DOI: $10.1177 / 0886260518785378$

Ali, Parveen Azam, Maria Irma Bustamante Gavino (2008) "Violence against Women in Pakistan: A Framework for Analysis", J Pak Med Assoc, 58, 4, 198-203.

Ali, Parveen Azam, Paul B. Naylor, Elizabeth Croot, and Alicia O'Cathain (2014) "Intimate Partner Violence in Pakistan: A Systematic Review". Trauma, Violence, \& Abuse, 299-315. DOI: 10.1177/1524838014526065

Ali, Tanvir, Muhammad Zakaria, Yousuf Hassan, and Munir Ahmad (2005) "Effect of Education on Gender Violence in the Context of Rural Farm Families of Tehsil Dera Ghazi Khan-Pakistan". Journal of Agriculture E Social Sciences, 1, 3, 227-230.

Ali, Tazeen Saeed (2016) "50\% of Pakistani women suffer domestic violence, reports the Dawn," The Times of India, November 6, 2016.

Ali, Tazeen Saeed, Ingrid Mogren, and Gunilla Krantz (2011) "Intimate partner violence and mental health effects: A population-based study among married women in Karachi, Pakistan". International Journal of Behavioral Medicine, 20, 1, 131-139. DOI:10.1007/s12529-011-9201-6

Ali, Tazin Saeed and I. Bustamante-Gavino (2007) "Prevalence of and Reasons for Domestic Violence among Women from Low Socioeconomic Communities of Karachi”. Eastern Mediterranean Health Journal, 13, 6, 1417-1426.

Ali, Waqar, Suhail Anwer Khan, Nizar Ahmad and Syed Rashid Ali (2015) "Understanding the Moral Justification for Domestic Violence against Women in Pakhtun Society: A Survey Research". The Discourse, 1, 1, 25-30.

Al-Najdī, Faisal bin Abdul Azīz, (2002) Tațīz Riyādh al-Salihīn. Riyadh: Dār al-Așimah.

Amir-ud-Din, Rafi, Shamim Fatima, and Shazia Aziz (2018) "Is Attitudinal Acceptance of Violence a Risk Factor? An Analysis of Domestic Violence against Women in Pakistan". Journal of Interpersonal Violence, 5.

Andersson, Neil, Anne Cockcroft, Noor Ansari, Khalid Omer, Ubaid Ullah Chaudhry Amir Khan and LuWei Pearson (2009) "Collecting Reliable Information about Violence against Women Safely in Household Interviews: Experience from a Large-Scale National Survey in South Asia". Violence against Women, 15, 4, 482-496. DOI: $10.1177 / 1077801208331063$

Andersson, Neil, Anne Cockcroft, Umaira Ansari, Khalid Omer, Noor M. Ansari, Amir Khan, and Ubaid Ullah Chaudhry (2009) "Barriers to Disclosing and Reporting Violence Among Women in Pakistan: Findings From a National Household Survey and Focus Group Discussions". Journal of Interpersonal Violence, 25, 11, 19651985, DOI: 10.1177/0886260509354512

An-Nasai, Ahmad bin Shu'aib (2007) Sunan An-Nasai, translated by Nasiruddin al-Khattab. Riyadh: Darussalam.

Ashraf, Sadia, Muhammad Abrar-ul-Haq, and Saba Ashraf (2017) "Domestic Violence against Women: Empirical Evidence from Pakistan”. Pertanika Journal of Social Science and Humanities, 25, 3, 1401-1418.

Asia Report $\mathrm{N}^{\circ} 265$ (2015) Women, Violence and Conflict in Pakistan. Belgium: International Crisis Group.

Aslam, Syeda Kanwal, Sidra Zaheer, and Kashif Shafique (2015) "Is spousal violence being "vertically transmitted" through victims? Findings from the Pakistan demographic and health survey 2012-13," PLoS ONE, 10, 6, 1-11, eo12979o, DOI:10.1371/journal.pone.0129790

At-Tirmidhī, Muhammad Ibn 'Eīsā (2007) Jāmi 'at-Tirmidhī, translated by Abu Khaliyl. Riyadh: Darussalam.

Awais, Sayema, Nimra Khan, Aashi Mughal, and Rizwana Chaudhri (2015) "Domestic Violence and its SocioDemographic Determinants among Women in Rawalpindi," JSOGP, 5, 4, 221-225.

Awan, Zia Ahmed (2004) “Violence against Women and Impediments in Access to Justice," assisted by: Lawyers for Human Rights and Legal Aid (LHRLA) Team.

Ayub, Muhammad, Muhammad Irfan, Tanvir Nasr, Muhammad Lutufullah, David Kingdon, and Farooq Naeem (2009) "Psychiatric morbidity and domestic violence: a survey of married women in Lahore," Social Psychiatry and Psychiatric Epidemiology, 44, 11, 953-96o, DOI:10.1007/soo127-0o9-0o16-6

Baalbaki, Rohi (1995) Al-Mawrid (Qamūs): A Modern English Arabic Dictionary, 7th ed. Beirut: Dar El-Ilm LilMalayin. 
Bachtrog, Doris, Judith E. Mank, Catherine L. Peichel, Mark Kirkpatrick, Sarah P. Otto, Tia-Lynn Ashman, Matthew W. Hahn, Jun Kitano, Itay Mayrose, Ray Ming, Nicolas Perrin, Laura Ross, Nicole Valenzuela, and Jana C. Vamosi (2014) “Sex Determination: Why So Many Ways of Doing It?" PLoS Biol, 12, 7, e1001899. DOI:10.1371/journal.pbio.1001899

Ballantine, C., Sabir, M., Ghaus, K. and Duvvury, N. (2017) Pakistan: The Economic and Social Impact of Violence against Women and Girls (VAWG). WhatWorks \& UKaid.

Bhattacharya, Sanchita (2014) "Status of Women in Pakistan". J.R.S.P., 51, 1, 179-211.

Bhatti, Nadeem, Muhammad Bachal Jamali, Najma Noor Phulpoto, Tariq Mehmood, and Faiz M. Shaikh (2011) “Domestic Violence against Women: A Case Study of District Jacobabad, Sindh Pakistan”. Asian Social Science, 7, 12, 146-162. DOI:10.5539/ass.v7n12p146

Bowden, Jeremiah J. (2013) "Marriageable Age in Islam: A Study on Marriageable Age Laws and Reforms in Islamic Law". LUX: A Journal of Transdisciplinary Writing and Research from Claremont Graduate University, 2, 1, Article. 5, 1-16. DOI: 10.5642/lux.201301.05

Bukhari, Amjad Ali, (2010) "Violence against Women in Southern Punjab: Altering Trends". Pakistan Journal of Social Sciences, 30, 1, 125-131, DOI=10.1.1.701.3326\&rep=rep1\&type=pdf

Bukhārī, Muhammad bin Ismail (1997) Sahīh al-Bukhārī, translated by Muhammad Muhsin Khan. Riyadh: Darussalam.

Chaudhry, Abid Ghafoor (2004) "Violence against Women: A Case Study". International Journal of Agriculture E Biology, 6, 4, 669-671.

Country Information and Guidance (2016) Pakistan: Women Fearing Gender Based Harm/ Violence. London: Independent Advisory Group on Country Information (IAGCI).

Devers, Lindsey, N. and Sarah Bacon (2010) “Interpreting Honor Crimes: The Institutional Disregard towards Female Victims of Family Violence in the Middle East”. International Journal of Criminology and Sociological Theory, 3, 1, 359-371.

Dildar, Saadia, Yasir Saeed and Sharjeela (2012) "Exploratory Study of the Nature of Violence against Elderly in District Gujrat, Pakistan”. Academic Research International, 2, 3, 661-669.

Farid, Mufiza, Sarah Saleem, Mehtab S. Karim, and Juanita Hatcher (2008) "Spousal abuse during pregnancy in Karachi, Pakistan," International Journal of Gynecology and Obstetrics, 101, 141-145.

Ferdous, Nahida, Russell Kabir, Hafiz T. A. Khan, Mohammad Rocky Khan Chowdhury (2017) "Exploring the relationship of Domestic Violence on Health Seeking Behavior and Empowerment of Women in Pakistan". Epidemiology Biostatistics and Public Health, 14, 1, e12231-7.

Fikree, Fariyal F., Junaid A. Razzak and Jill Durocher (2005) "Attitudes of Pakistani Men to Domestic Violence: A Study from Karachi, Pakistan”, Journal of Men's Health and Gender, 2, 1, 49-58.

Fikree, Fariyal F., Sadiqua N. Jafarey, Razia Korejo, Anjum Afshan and Jill M. Durocher (20o6) "Intimate Partner Violence before and during pregnancy: Experiences of postpartum women in Karachi, Pakistan”. J Pak Med Assoc, 56, 6, 252-257.

Finker, Kaja (1997) “Gender, Domestic Violence and Sickness in Mexico”. Social Science Medicine, 45, 1147-116o. DOI:10.1016/s0277-9536(97)0oo23-3

Ghani, Sarmad Ahmed (2016) "Violence against Women in Pakistan: A Study of Management Perspective of Gender Violence," JPUHS, 29, 2, 205-220.

Goody, Jack (1976) Production and Reproduction: A Comparative Study of the Domestic Domain. Cambridge: Cambridge University Press.

Gul Nayab, Abid Ghafoor Chaudhry, and Sadia Shafique (2018) “Contextualization of Women's Right to Marriage in Masid Tribal Society”. Anthropol Open Acc: AOAP-123. DOI: 10.29011/AOAP-123/100023

Gulzar, Shazia, Muhammad Nauman, Farzan Yahya, Shagafat Ali, and Mariam Yaqoob (2012) "Dowry System in Pakistan". Asian Economic and Financial Review, 2, 7, 784-794.

Habiba, Ume, Rabia Ali and Asia Ashfaq (2016) From Patriarchy to Neopatriarchy: Experiences of Women from Pakistan. International Journal of Humanities and Social Science, 6, 3, 212-221.

Hamid, Saima, Eva Johansson, and Birgitta Rubenson (2010) "Security lies in obedience - Voices of young women of a slum in Pakistan," BMC Public Health, 10, 1, 1-7.

Haqqi, Sobia and Abdul Faizi (2010) "Prevalence of Domestic Violence and associated Depression in married women at a Tertiary care hospital in Karachi”. Procedia Social and Behavioral Sciences, 5, $1090-1097$. DOI:10.1016/j.sbspro.2010.07.241

Human Rights Commission of Pakistan (2013) State of Human Rights in 2012. Lahore: Human Rights Commission of Pakistan.

Hussain, Mohammed Subhan (2018) “Islamic Law on Child Marriages”. NILS UK Law Review, 1, $163-174$.

Hussain, Mubashir (2003) Hadiya-Tul-Uroos. Lahore, Nomani Kutub Khana. 
Hussain, Rafat, and Adeel Khan (2008) “Women's Perceptions and Experiences of Sexual Violence in Marital Relationships and Its Effect on Reproductive Health". 29, 5, 468-483. DOI:10.1080/o7399330801949541

Ibad, Mahnoor, and Saeeda Batool (2017) “Domestic Violence and Woman's Functional Capabilities: Circularity Analysis in Sen's Development Framework". S3H Working Paper Series, 1-29.

Ibn Hibbān, Muhammad bin Hibbān (1993) Șahīh Ibn Hibbān. Beirut: Mu'assasah Al-Risālah.

Ibn Mājah, Muhammad bin Yazeed (2007) Sunan Ibn Mājah, translated by Nasiruddin al-Khattab. Riyadh: Darussalam.

Ibrahim, Nada, and Mohamad Abdalla (2010) "A Critical Examination of Qur'an 4:34 and Its Relevance to Intimate Partner Violence in Muslim Families", Journal of Muslim Mental Health, 5, 3, 327-349.

Ilyas, Mirza and Rachel Jenkins, "Risk Factors, Prevalence and Treatment of Anxiety and Depressive Disorders in Pakistan: Systematic Review,” BMJ, 328, 7443, 1-55.

Iqbal, Meesha, and Zafar Fatmi (2018) "Prevalence of Emotional and Physical Intimate Partner Violence among Married Women in Pakistan”, Journal of Interpersonal Violence, 1-16.

Islahi, Amin Ahsan (2009) Islami Mo’ashirah main Aurat ka Muqām. Lahore: Faran Foundation.

Jalil, Aisha, Rubeena Zakar, and Shazia Qureshi (2013) "Physical Wife Abuse in Rural Sindh, Pakistan: Prevalence, Protective and Risk Factors". Journal of the Research Society of Pakistan, 50, 1, 171-194.

Kakakhel, Ijaz (2019) "Senate panel approves bill to raise marriage age limit to 18 years". Daily Times: January 31, 2019, accessed March 5, 2019, https://dailytimes.com.pk/349718/senate-panel-approves-bill-to-raisemarriage-age-limit-to-18-years/

Kapadia, Mufiza Zia, Sarah Saleem, and Mehtab S. Karim (2010) “The hidden figure: sexual intimate partner violence among Pakistani women”. European Journal of Public Health 20, 2, 164-168.

Karmaliani, Rozina, Nargis Asad, Kausar S. Khan, Sohail Bawani, Tazeen Saeed Ali, Nicola Jones, Taveeshi Gupta, Anita Allana, Hussain Maqbool, David Walker (2017) Understanding Intimate Partner Violence in Pakistan through a Male Lens. London: Overseas Development Institute.

Kelly, Liz, \& Regan, Linda, (2006) Violence against Women: A briefing document on international issues and responses. Manchester: British Council.

Khan Mahjabeen, Sina Aziz, Nasreen Qamar, Jalil Qadir Memon (2014) "Frequent Factors for Women and Children Subjected to Sexual Assaults Presenting at Jinnah Postgraduate Medical Center, Karachi”. Journal of Pakistan Medical Association, 64, 6, 649-652.

Khan, Azmat J., Tazeen S. Ali and Ali K. Khuwaja (2009) “Domestic Violence among Pakistani Women: An Insight into Literature". Isra Medical Journal, 1, 2, 54-56.

Khan, Muhammad Danyal, Fraz Ashraf Khan, Muhammad Daniyal, and Abdul Basit (2019) "Domestic Violence against Women: Statistical Analysis and Legislative Solutions”. European Online Journal of Natural and Social Sciences, 8, 2, 374-380.

Khan, Sarfraz and Mirza Rizwan Sajid (2011) "Violence against Women in Pakistan: A case study of wife battering in rural Gujrat, Pakistan”. World Applied Sciences Journal, 12, 11, 2168-2174.

Khatoon, Haleema, Aneela Maqsood, Farah Qadir, and Farid A. Minhas (2014) "Prevalence of Anxiety among Children Exposed to Inter-Parental Domestic Violence: Proportional Ratio between Community Sample and Shelter Home Sample”. Journal of Pakistan Psychiatric Society, 11, 1, 14-17.

Khawaja, Asma Shakir (2017) “Women in Security Policy-making: A Case Study of Pakistan”. Strategic Studies, $37,1,98$.

Khoso, Abdullah (2013) Child Marriages in Pakistan. Institute for Social Justice (ISJ). www.isj.org.pk.

Krippendorff, Klaus (2003) Content Analysis: An Introduction to its Methodology. Thousand Oaks: SAGE Publications.

Kumar, Ankur (2010) “Domestic Violence against Women: Causes, Effects and Remedies," accessed July 6, 2019 from https://www.youthkiawaaz.com/2010/o2/domestic-violence-in-india-causes-consequences-and-remedies-2/

LaBore, Kathryn, Tooba Ahmed, and Rizwan-ur-Rashid (2019) "Prevalence and Predictors of Violence against Women in Pakistan”. Journal of Interpersonal Violence, 1-18. DOI:10.1177/0886260518824652

Laila Tul Qadar, Osama Shabbir and Fauzia Imtiaz (2018) "Violence against women in Pakistan - A cultural or a criminal problem?" Editorial in International Journal on Women Empowerment, 3-4, https://doi.org/10.29052/2413-4252.v4.i1.2018.3-4

LEAD Pakistan (2019) “Domestic Violence”. Accessed July 6, 2019, http://www.lead.org.pk/hr/attachments/issues/Domestic\%2oviolence.pdf

Lieven, Anatol (2011) Pakistan a Hard Country. London: Penguin Books Limited.

Madhani, Farhana I., Rozina Karmaliani, Cyra Patel, Carla M. Bann, Elizabeth M. McClure, Omrana Pasha, and Robert L. Goldenberg (2017) “Women's Perceptions and Experiences of Domestic Violence: An Observational Study from Hyderabad, Pakistan”. J Interpers Violence, 32, 1, 766-100, DOI:10.1177/o886260515585533 
Manzoor, Rabia, Muhammad Abdul-Rahman, \& Mehreen Bano (2013) "Violence against women in Pakistan: Evidence from Punjab”. International Journal of Advanced Research, 1, 6, 356-365.

Manzoor, Rabia, Sana Ejaz Khan, and Nadia Manzoor (2013) "Domestic violence against women and its perceptions \& experiences: An analysis from the perspective of KPK, Pakistan,” International Journal of Advanced Research, $1,9,859-869$.

Maududi, Abul A'la (1987) Purdah and the Status of Woman in Islam. Translated and edited by Al-Ash'ari. Lahore: Islamic Publications.

Merry, Sally Engle (2006) "Human Rights and Transnational Culture: Regulating Gender Violence through Global Law” Osgoode Hall Law Journal, 44, 1, 53-75.

Muneer, Sania (2017) "Pro-women Laws in Pakistan: Challenges towards Implementation". Pakistan Vision, 18, 2, 86-101.

Muslim Family Law Ordinance (1961) s12 (1) (c). http://punjablaws.gov.pk/laws/777a.html

Muslim Ibn Al-Hajjaj, (2007) Sahīh Muslim, translated by Nasiruddin Al-khatab. Riyadh: Darussalam.

Nasir, Adnan, Abid Ghafoor Chaudhry, Aftab Ahmed and Haris Farooq (2014) "Rural Conflicts and Alliance Formation: A Cultural Strategy". Global Journal of Human-Social Science, XIV, VIII, I, 1-5.

National Domestic Violence Hotline (2019) "National Center for Victims of Crime, and Women's Law Organisation", accessed July 6, 2019, from WomensLaw.org.

National Institute of Population Studies Pakistan and ICF International USA (2013) Pakistan Demographic and Health Survey 2012-13. Islamabad: National Institute of Population Studies.

Niaz, Unaiza and Sehar Hassan (2006) "Culture and mental health of women in South-East Asia". World Psychiatry, $5,2,118-120$.

Noor, Muhammad Jehanzeb (2004) Daughters of Eve: Violence against Women in Pakistan. BS thesis: Massachusetts Institute of Technology, USA.

Nosheen, Humaira (2011) "Violence against Women". The Dialogue, VI, 3, $290-299$. http://www.qurtuba.edu.pk/thedialogue/The\%2oDialogue/6_3/Dialogue_July_September2011_290-299.pdf

Offenhauer, Priscilla (2005) "Women in Islamic Societies: A Selected Review of Social Scientific Literature". Washington DC: Library of Congress.

Parveen, Rakhshinda (2012) Annual Report 2012: Violence against Women in Pakistan. Islamabad: Aurat Foundation. Pilcher, Jane and Imelda Whelehan (2004) 50 Key Concepts in Gender Studies. London: SAGE Publications.

Pingley, Terra (2017) The Impact of Witnessing Domestic Violence on Children: A Systematic Review. Available at: https://sophia.stkate.edu/msw_papers/776

Psych Central (2020) "Understanding the Effects of Domestic Violence”. Psych Central. Retrieved on February 22, 2020, from https://psychcentral.com/lib/understanding-the-effects-of-domestic-violence/

Qaisrani, Ayesha, Sadaf Liaquat, and Elishma Noel Khokhar (2016) "Socio-economic and Cultural Factors of Violence”. Islamabad: Sustainable Development Policy Institute.

Qayum, Mehran, Sundas Mohmand, and Hina Arooj (2012) "Frequency and Physical Factors Associated with Gender-Based Violence in the Internally Displaced People of Pakistan”. Journal of the College of Physicians and Surgeons Pakistan, 22, 1, 63-65.

Rabbani, F., Qureshi, F., and Rizvi, F. (2008) "Perspectives on domestic violence: case study from Karachi, Pakistan”. Eastern Mediterranean Health Journal, 14, 2, 415-426.

Rizvi, Narjis, Anam Feroz, Saba Pervez, Oyinlola Oyebode (2019) "Prevalence and Factors Associated with Violence against Women in Pakistan”. J Women's Health Gyn, 6: 1-12.

Saddique, Hafiz Muhammad (2017) The Role of Pakistani Judiciary in Protecting women's Rights in Family Matters. Islamabad: Ph.D. Dissertation, International Islamic University, Islamabad.

Saeed, Muhammad (2012) Pakhtun Men's Perceptions of the Conditions Promoting Domestic Violence in their Culture. England: PhD dissertation, Centre for Women's Studies, The University of York.

Schwandt, Thomas A. (2001) Dictionary of Qualitative Inquiry. Thousands Oak, CA: SAGE.

Shah, Mian Mujahid, Naveed Alam, Qudsia Hassan, Sahibdad Khan, Iftikhar Qayum, Sher Bahadur, and Zahid Hussain Khalil (2012) "Death in the Home: Domestic Violence against Women in Khyber Pakhtunkhwa". J Ayub Med Coll Abbottabad, 24, 1, 48-51.

Shaikh, Masood Ali (200o) “Domestic Violence Against Women--Perspective From Pakistan”. J Pak Med Assoc, 50, 9, 312-4.

Shaikh, Masood Ali (2003) "Is Domestic Violence Endemic in Pakistan: Perspective from Pakistani Wives". J Pak Med Assoc, 19, 1, 23.

Shaikh, Masood Ali (2016) "Domestic violence in consanguineous marriages - findings from Pakistan Demographic and Health Survey 2012-13". J Pak Med Assoc, 66, 10, 1319-1323. 
Siddiqui, Rehana, Shahnaz Hamid, and Rizwana Siddiqui (2015) "Analysis of Non-conventional Indicators of Gender Relations: Evidence from Pakistan”. The Pakistan Development Review, 39, 4, 913-929.

Social Policy and Development Center (2012) Socio-economic Cost of Violence against Women. Available at: ttp://www.spdc.org.pk/Data/Publication/PDF/GRP\%2oRR5.pdf

Spitzberg, Brian (ed) (2009) Aggression, Violence, and Hurt in Close Relationships. Cambridge: University Press.

Sultan, Hina, Amina Obaid Khawaja, and Tehziba Kousir (2016) "Spousal Abuse among Pakistani Women: A Thematic Analysis". Pakistan Journal of Social and Clinical Psychology, 14, 2, 33-41.

Sultana, Abeda (2012) Patriarchy and Women's Subordination: A Theoretical Analysis. Arts Faculty Journal, 4, 1-18. DOI:10.3329/afj.v4io.12929

Tabassum, Naima (2016) Women in Pakistan: Status in Socio-Cultural and Politico-Legal Domains. Islamabad-Pakistan: Higher Education Commission (HEC). Available at: http://prr.hec.gov.pk/jspui/handle/123456789/28

Tarar, Maliha Gull and Venkat Pulla (2014) "Patriarchy, Gender Violence and Poverty amongst Pakistani Women: A Social Work Inquiry". International Journal of Social Work and Human Services Practice, 2, 2, 56-63.

The UN (1995) World Conference on Women. Beijing Declaration and Platform for Action. https://www.un.org/en/events/pastevents/pdfs/Beijing_Declaration_and_Platform_for_Action.pdf

Thomson Reuters Foundation Annual Poll in 2018, https://poll2018.trust.org/

United Nations Children's Fund (UNICEF) (200o) Domestic Violence against Women and Girls. Florence, Italy: Innocenti Research Centre.

Usman, Ayesha (2018) "A Sociological Study on Violence against Women in Pakistan; Challenges and Solutions". Global Media Journal, 16, 31:115, 1-11.

Wahed, Tania, and Abbas Bhuiya (2007) "Battered Bodies \& Shattered Minds: Violence against Women in Bangladesh". Indian Journal of Medical Research, 126, 341-354.

Wasim, Mohammad Pervez, Gobind M. Herani, Wahid Farooqui, and M. A. Qureshi (2008) "Family types, authority structure and women workers in Sindh labor force: Problems and prospects," Indus Journal of Management $\mathcal{E}$ Social Sciences, 2, 29-49.

Weber, R. P. (1990) Basic Content Analysis. Newbury Park: Sage Publications.

Welchman, Lynn, and Sara Hossain (eds) (2005) 'Honour': Crimes, Paradigms and Violence Against Women. London: Zed Books, 1-21.

WHO \& PAHO (2012) "Understanding and addressing violence against women". World Health Organization \& Pan American Health Organization.

Wodon, Quentin (2015) Child Marriage, Family Law, and Religion: An Introduction to the Fall 2015 Issue. The Review of Faith \& International Affairs, 13, 3, 1-5, DOI: 10.1080/15570274.2015.1075761

Women-Rights of the disadvantaged (2015) accessed July 6, 2019, http://hrcpweb.org/hrcpweb/wpcontent/uploads/2016/o4/Women_12.pdf.

World Health Organization (WHO) (1996) Consultation, Violence against Women. Geneva: WHO. Available at: https://apps.who.int/iris/handle/10665/63277

World Health Organization (WHO) (2013) Global and regional estimates of violence against women: prevalence and health effects of intimate partner violence and non-partner sexual violence. Geneva: World Health Organization. Available at: https://apps.who.int/iris/handle/10665/85239

World Health Organization (WHO) (2017) Violence against Women - Intimate Partner Sexual Violence, Geneva: World Health Organization. Available at: http://www.who.int/mediacentre/factsheets/fs239/en/Factsheet

Yasien, Saba, Tabassum Alvi, Washdev, and Fazeela Moghal (2018) "Intimate Partner Violence during Pregnancy and its Outcome". Pakistan Armed Forces M J, 68, 5, 1429-1433.

Zainab, Saima, Zafar Fatmi, Ambreen Kazi (2012) "Risk factors for depression among married women belonging to higher and lower socioeconomic status in Karachi, Pakistan". Journal of the Pakistan Medical Association, 62, 3, 249-253.

Zakar, Rubeena, Muhammad Z. Zakar, Rafael Mikolajczyk, and Alexander Krämer (2012) "Intimate Partner Violence and its Association with Women's Reproductive Health in Pakistan”. International Journal of Gynecology $\mathcal{E}$ Obstetrics, 117, 1, 10-14. DOI:10.1016/j.ijgo.2011.10.032

Zareen, Nabila, Nasreen Majid, Sonia Naqvi, Sadia Saboohi and Hassan Fatima (2009) "Effect of domestic violence on pregnancy outcome". Journal of College of Physicians \& Surgeons Pakistan, 19, 5, 291-296. DOI: 05.2009/JCPSP.291296

Zia-Ullah, Muhammad (2010) Honour Killings in Pakistan under Theoretical, Legal and Religious Perspectives. Sweden: Master's Thesis, Malmö University Malmö, http://muep.mau.se/handle/2043/10419 